\title{
Tissue-specific gene expression in rat hearts and aortas in a model of vascular
}

nitrate tolerance

Tamás Csont, MD, $\mathrm{PhD}^{1 *}$, Zsolt Murlasits, MSc, $\mathrm{PhD}^{2}$, Dalma Ménesi, $\mathrm{MSc}^{3}$, János Z. Kelemen, $M S c, \mathrm{PhD}^{3}$, Péter Bencsik, $\mathrm{MD}, \mathrm{PhD}^{2}$, Márton Pipicz, $\mathrm{MD}^{1}$, Veronika Fekete $\mathrm{MD}^{1}$, Ágnes Zvara, MSc, $\mathrm{PhD}^{3}$,

László G. Puskás, MSc, PhD, DSc ${ }^{3}$, Péter Ferdinandy, MD, PhD, DSc ${ }^{1,2,4}$

${ }^{1}$ Department of Biochemistry, University of Szeged, Szeged, Hungary

${ }^{2}$ Pharmahungary Group, Szeged, Hungary

${ }^{3}$ Institute of Genetics, Biological Research Center, Hungarian Academy of Sciences, Szeged, Hungary

${ }^{4}$ Department of Pharmacology and Pharmacotherapy, Semmelweis University, Budapest, Hungary

*To whom correspondence should be addressed at the Department of Biochemistry, University of Szeged, Dóm tér 9, Szeged, H-6720, Hungary; Tel: +36 62 545096; Fax: +3662545097

E-mail: csont.tamas@med.u-szeged.hu

Running title: Nitrate tolerance and gene expression in the heart and aorta

Word count: 5908

Conflict of interest: Nothing to declare.

Acknowledgements: We are grateful to Dr. Gábor Szénási for kindly donating nitroglycerin for the present study, as well as to Anthony Hernandes for proofreading the manuscript. We acknowledge the support of grants from the Hungarian Scientific Research Fund (K79167), the National Office for Research and Technology (JedlikMed-Food-2008), and the European Social Fund (TÁMOP-4.2.2.A-11/1/KONV-20120035). This work was also supported by the János Bolyai Research Scholarship of the Hungarian Academy of Sciences (TC). PF is a Szentágothai Fellow of the Hungarian National Program of Excellence (TÁMOP 4.2.4.A/2-11-1-2012-0001). 


\section{Abstract}

Nitroglycerin exerts a direct myocardial anti-ischemic effect even in the state of vascular nitrate tolerance. To examine the potentially diverse molecular responses in vascular and cardiac tissues, we investigated the gene expression profile of the heart and the aorta by DNA microarray in male Wistar rats that were previously made tolerant to the vascular effects of nitroglycerin. The blood pressure lowering effect of nitroglycerin $(1-100 \mu \mathrm{g} / \mathrm{kg})$ was markedly attenuated in rats pre-treated for 3 days with $3 \times 100 \mathrm{mg} / \mathrm{kg}$ nitroglycerin. Nitric oxide content was significantly elevated in the heart but not in the aorta of nitrate-tolerant animals, which indicated tissuespecific differences in nitroglycerin bioconversion. Out of 7742 genes analyzed by DNA microarray, we found that while the expression of 25 genes changed significantly in the heart (increased: Tas2r119, Map6, Cd59, Kcnh2, Kcnh3, Senp6, Mcpt1, Tshb, Haus1, Vipr1, Lrn3, Lifr; decreased: Ihh, Fgfr1, Cryge, Krt9, Agrn, C4bpb, Fcer1a, Csf3, Hsd17b11, Hsd11b2, Ctnnbl1, Prpg1, Hsf1), only 14 genes were altered in the aorta (increased: Tas2r119, Ihh, Rrad, Npm1, Snai1; decreased: Tubb2b, Usp15, Sema6c, Wfdc2, Rps21, Ramp2, Galr1, Atxn1, Lhx1) in vascular nitrate tolerance. QRT-PCR analysis of genes related to oxidative/nitrative/nitrosative stress also showed differential expression pattern in the heart and aorta. This is the first pharmacogenomic analysis showing that nitroglycerin treatment leading to vascular nitrate tolerance differentially impacts gene expression in vascular and cardiac tissues, which indicates different tissue-specific downstream signaling pathways.

Keywords: NOX; NOX4; matrix metalloproteinase; SOD; heat shock; 


\section{Introduction}

Organic nitrates have been among the most widely used drugs for the treatment of ischemic heart disease, a leading cause of death, for more than a century. The major effect of nitrates has been attributed to their vasodilator function and the resulting reduction of cardiac preload and afterload. However, development of vascular tolerance due to prolonged use reduces the clinical effectiveness of nitrate therapy. The principal causes of vascular nitrate tolerance are believed to be decreased bioavailability of nitric oxide (NO) derived from nitrates, counter-regulatory neurohormone activation and oxidative/nitrative/nitrosative stress ${ }^{1,2}$. Despite the potential for tolerance development, chronic nitrate use was associated with a shift away from ST-segment elevation myocardial infarction to non-ST-segment elevation acute coronary syndrome with smaller release of myocardial necrotic markers in a large scale clinical trial ${ }^{3}$.

Interestingly, nitrates also exert a direct myocardial anti-ischemic effect, which is independent of their hemodynamic action and is preserved even in the state of vascular nitrate tolerance ${ }^{2,4,5}$. Moreover, Hill and coworkers ${ }^{6}$ have demonstrated in rabbit hearts that nitroglycerin treatment elicited a preconditioning-like effect comparable to ischemia-induced preconditioning, which was sustained even during development of nitrate tolerance. To explain the mechanisms of these phenomena, we have previously shown $n^{4,7}$ by spin trapping measurement of NO levels in nitratetolerant and non-tolerant hearts that in contrast to vascular tissue, the bioconversion of nitroglycerin is not blunted in the myocardium. We have also found that oxidative stress was not increased in the heart during nitrate tolerance ${ }^{8}$. Based on these findings, it was proposed that the vasculature and cardiac tissue may respond to nitroglycerin treatment in a different way, questioning the existence of myocardial 
nitrate tolerance ${ }^{2}$. To date, there is insufficient data regarding the potentially diverse cellular responses of vascular and cardiac tissues to organic nitrate treatments leading to the development of vascular nitrate tolerance, though the mechanism of nitrate action likely differ in these cell types ${ }^{2}$. Therefore, here we used DNA microarray analysis and QRT-PCR to monitor transcript levels in rat hearts and aortas with the hope of identifying critical differences in these tissues in response to nitroglycerin treatment which leads to vascular nitrate tolerance.

\section{Methods}

The study conforms to the 'Guide for the care and use of laboratory animals' published by the US National Institutes of Health (NIH publication No. 85-23, revised 1996) and was approved by local ethics committees. The animals were kept at 12hour light/dark cycle and had free access to standard laboratory chow and drinking water.

\subsection{Nitrate treatment and verification of vascular nitrate tolerance}

To induce vascular nitrate tolerance (Figure 1.), male Wistar rats (300-360 g) were given nitroglycerin (100 mg/kg subcutaneously) or its vehicle (lactose) 3 times a day for 3 days as described in our earlier studies ${ }^{5,8,9}$. The animals were used for biochemical measurements on the fourth day (Figure 1.), approximately $12 \mathrm{~h}$ after the last injection, while the development of vascular tolerance to nitroglycerin was confirmed in a subgroup ( $\mathrm{n}=4$ in each group) of animals in vivo (Figure 1.), according to the following protocol. The rats were anesthetized with an intraperitoneal injection of $60 \mathrm{mg} / \mathrm{kg}$ sodium pentobarbital, intubated via the trachea and then connected to a small animal respirator whose frequency and volume were 
set at $50-55 / \mathrm{min}$ and $2.5 \mathrm{~mL}$, respectively. The right carotid artery was isolated and a catheter (which was connected to a pressure transducer) was inserted for blood pressure (BP) monitoring. Similarly, the right jugular vein was isolated and catheterized for nitroglycerin administration. Body temperature was maintained at $37 \pm 1{ }^{\circ} \mathrm{C}$ throughout the experiment ${ }^{9}$. The test of vascular nitrate tolerance was conducted by recording the acute BP responses to intravenous administration of increasing doses of nitroglycerin $(1 \mu \mathrm{g} / \mathrm{kg}, \quad 3 \mu \mathrm{g} / \mathrm{kg}, \quad 10 \mu \mathrm{g} / \mathrm{kg}, 30 \mu \mathrm{g} / \mathrm{kg}$, and $100 \mu \mathrm{g} / \mathrm{kg}$ ), in ten-minute intervals. The maximal BP-lowering effect was noted following administration of each nitroglycerin dose.

2.2. Determination of cardiac and vascular NO content by electron paramagnetic resonance (EPR)

To study potential tissue-specific differences in the metabolism of nitroglycerin, cardiac and aortic NO was measured by EPR after in vivo spin trapping from rats that were subjected to repeated nitroglycerin or vehicle injections. The spin trap diethyl-dithio-carbamate (DETC, $200 \mathrm{mg} / \mathrm{kg}$ ), $50 \mathrm{mg} / \mathrm{kg} \mathrm{FeSO} 4$ and $200 \mathrm{mg} / \mathrm{kg}$ sodium-citrate were slowly administered intravenously into the femoral vein under ether anesthesia as described earlier ${ }^{10}$. DETC dissolved in distilled water was injected separately from $\mathrm{FeSO}_{4}$ and sodium-citrate, to avoid precipitation of $\mathrm{Fe}^{2+}$ $(\mathrm{DETC})_{2}$. Sodium-citrate and $\mathrm{FeSO}_{4}$ were dissolved in distilled water and $\mathrm{pH}$ was set to 7.4 with $\mathrm{NaOH}$. Five minutes after DETC, $\mathrm{FeSO}_{4}$, and citrate treatment, the heart and the thoracic and abdominal aorta were isolated, rinsed in saline, and approximately $150 \mathrm{mg}$ of the left ventricle and the entire aorta were placed into quartz EPR tubes and frozen in liquid nitrogen until assayed for EPR spectra of NO$\mathrm{Fe}^{2+}-(\mathrm{DETC})_{2}$ complex, as described earlier ${ }^{7,10}$. 


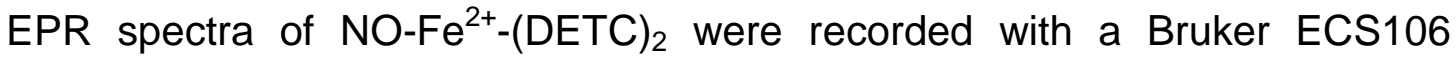
spectrometer (Rheinstetten, Germany; ESR parameters: X band, $100-\mathrm{kHz}$ modulation frequency, $160-\mathrm{K}$ temperature, $10-\mathrm{mW}$ microwave power, $2.85-\mathrm{G}$ modulation amplitude, 3356-G central field). Spectra were analyzed for NO signal intensity as described earlier ${ }^{7,10}$. Cardiac and aortic NO content were expressed as arbitrary units.

\subsection{Isolation of the heart and aorta for RNA preparation}

Animals were anesthetized with diethyl ether and given $500 \mathrm{U} / \mathrm{kg}$ heparin intravenously. Hearts from control and nitrate-treated rats ( $n=8$ in each groups) were then isolated and perfused in Langendorff mode with oxygenated, normothermic Krebs-Henseleit buffer for $5 \mathrm{~min}$, as described in earlier works ${ }^{4}$. Following isolation of the heart, the entire thoracic and abdominal aorta was dissected, placed in ice cold saline and trimmed of excess connective tissue. Then the ventricles and aortas from both experimental groups were blotted, immediately frozen, and powdered with a pestle and mortar in liquid nitrogen for RNA preparation.

\subsection{RNA preparation}

Total RNA was purified from each group ( $25 \mathrm{mg}$ tissue from each sample) with NucleoSpin RNA purification kit (Macherey-Nagel, Dürren, Germany) according to the manufacturer's instructions. The quantities and qualities of RNA from each sample were assessed by gel electrophoresis as well as spectrophotometry (NanoDrop spectrophotometer, NanoDrop, USA). Two RNA pools were prepared from each group ( $n=4$, randomly selected from each group) and used in replica 
experiments. Total RNA was used for microarray analysis as well as for reverse transcription and subsequent quantitative PCR.

\subsection{Microarray analysis}

To monitor tissue-specific differences at the molecular level in cardiac and aortic tissues in response to nitroglycerin treatment that leads to vascular nitrate tolerance, we performed DNA microarray analysis. Microarray probes were generated by a modified version of a linear amplification technique described previously ${ }^{11}$. Briefly, two $\mu \mathrm{g}$ of total RNA from each pooled sample was amplified. Three $\mu \mathrm{g}$ of amplified RNA was labeled with both Cy5 and Cy3 fluorescent dyes (dye-swap experiments) during reverse transcription (RT) with RNAse $\mathrm{H}$ point mutant M-MLV reverse transcriptase (Fermentas, Vilnius, Lithuania) and random nonamers. After RT, RNA was alkali hydrolyzed and labeled cDNA was purified with NucleoSpin ${ }^{T M}$ PCR purification kit (Macherey-Nagel) according to the manufacturer's instructions. Probes generated from the control and treated samples were mixed, reconstituted in $16 \mu \mathrm{L}$ hybridization buffer ( $50 \%$ formamide, $5 \times$ SSC, $0.1 \%$ SDS, $100 \mu \mathrm{g} / \mathrm{mL}$ salmon sperm DNA) and applied onto the array after denaturation by heating for $1 \mathrm{~min}$ at $90^{\circ} \mathrm{C}$. Slides were incubated at $42{ }^{\circ} \mathrm{C}$ for 20 hours in a humid hybridization chamber. After hybridization the arrays were washed by submersion and agitation for $10 \mathrm{~min}$ in $1 \times$ SSC with $0.1 \%$ SDS, for $10 \mathrm{~min}$ in $0.1 \times$ SSC with $0.1 \%$ SDS and for $10 \mathrm{~min}$ in $0.1 \times \mathrm{SSC}$ at room temperature, then rinsed briefly in water and dried.

Each array was scanned under a green laser (543 nm for Cy3 labeling) or a red laser (633 nm for Cy5 labeling) using a ScanArray Lite (GSI Lumonics, Billerica, MA) scanning confocal fluorescent scanner with $10 \mu \mathrm{m}$ resolution (Laser power: 85\% 
for Cy 5 and $90 \%$ for Cy3, Gain: $75 \%$ for Cy 5 and $70 \%$ for Cy3). Scanned output files were analyzed using the GenePix Pro 3.0 software (Axon Instruments Inc., Foster City, CA). Each spot was defined by automatic positioning of a grid of circles over the image. The average and median pixel intensity ratios calculated from both channels and the local background of each spot were determined. An average expression ratio (MeaR, denotes the average of local background corrected pixel intensity ratios) was determined for each spot. Normalization was performed by the global Lowess method. Those data were flagged and excluded where the replicate spots from a different site of the same array or results from the replicate experiments were significantly different. Data analysis was done by the Significance Analysis of Microarrays (SAM) method. Calculating the fold change in average between heart or aorta samples from non-tolerant and nitroglycerin-tolerant animals determined gene expression responses. From two biological replicates and two hybridizations, altogether four data points were gathered from each gene. Genes for which the average- $\log 2$ ratio (increase or decrease) of the four data points was at least 0.90 and $p<0.05$ were considered as genes affected by nitrate tolerance.

\subsection{Real-time quantitative PCR}

The confirmatory QRT-PCR was performed on a RotorGene 2000 instrument (Corbett Research, Sydney, Australia) with gene-specific primers and SybrGreen protocol to confirm the gene expression changes observed by DNA microarrays as described ${ }^{12}$. Fluorescent signals were gathered after each extension step at $72{ }^{\circ} \mathrm{C}$. Curves were analyzed by the RotorGene software using dynamic tube and slope correction methods, ignoring data from cycles close to baseline. Relative expression ratios were normalized to beta-actin and calculated with the Pfaffl method. The PCR primers used in this study are listed in Supplementary Material 1. A. Primers were 
designed by using the ArrayExpress software (Applied Biosystems). All the PCRs were performed four times in separate runs.

We also conducted additional QRT-PCR analyses of genes that are related to oxidative/nitrative/nitrosative stress and were not available on the microarray. The protocol for these analyses was identical to the above described method for the confirmatory QRT-PCR. The primers used in these analyses are listed in Supplementary Material 1. In separate experiments, additional QRT-PCR was conducted focusing on transcript levels of selected vascular signaling molecules (Supplementary Material 2.).

\subsection{Statistics}

Gene expression with $p<0.05$ and $\log _{2}$ ratio $\geq 0.90$ or $\log _{2}$ ratio $\leq-0.90$ (1.87 fold change) were considered as significant up- or down-regulation, respectively. One-way ANOVA or unpaired t-test, as appropriate, was used to calculate the differences in other parameters, such as the hemodynamic values or tissue nitric oxide content, between groups $(p<0.05)$.

\section{Results}

As expected, nitrate-tolerant animals exhibited a significantly attenuated acute blood pressure response during our nitroglycerin tolerance test (for explanation see the methods section) (Figure 2). However, there were no differences in body weight, heart weight, and basal ex vivo hemodynamic parameters between the nitratetolerant and the non-tolerant rats (Table 1).

To study potential tissue-specific differences in the metabolism of nitroglycerin, cardiac and aortic NO content were measured by EPR after in vivo spin 
trapping from rats that were subjected to repeated nitroglycerin or vehicle injections. Nitric oxide content was significantly elevated in the heart but not in the aorta of nitrate-tolerant animals when compared to non-tolerant controls (Figure 3).

To assess tissue-specific responses to repeated nitroglycerin pretreatments at the transcript level, expression of 7742 genes were analyzed by DNA microarray and the expression of 25 genes changed significantly in the heart, while 14 genes were altered in the aorta in vascular nitrate tolerance.

The result of the analysis indicates that the expression of twelve genes increased (taste receptor type 2 member 119, microtubule-associated protein 6, CD59 molecule, potassium voltage-gated channel subfamily $\mathrm{H}$ member 2, potassium voltage-gated channel subfamily $\mathrm{H}$ member 3 , SUMO1/sentrin specific peptidase 6 , mast cell protease 1, thyroid stimulating hormone beta, HAUS augmin-like complex subunit 1, vasoactive intestinal peptide receptor 1 , leucine rich repeat neuronal 3 , leukemia inhibitory factor receptor alpha) and thirteen genes decreased (indian hedgehog, fibroblast growth factor receptor 1 , crystallin gamma $\mathrm{E}$, keratin 9, agrin, complement component 4 binding protein beta, Fc fragment of $\operatorname{lgE}$, colony stimulating factor 3, hydroxysteroid (17-beta) dehydrogenase 11, hydroxysteroid 11beta dehydrogenase 2 , catenin beta like 1, proline-rich proteoglycan 1 , heat shock transcription factor 1 ) in the heart (Table 2 and Table 3), while five increased (taste receptor type 2 member 119, indian hedgehog, ras-related associated with diabetes, nucleophosmin, snail family zinc finger 1) and nine decreased (tubulin beta 2B class IIb, ubiquitin specific peptidase 15 , semaphoring $6 \mathrm{C}$, WAP four-disulfide core domain 2, ribosomal protein $\$ 21$, receptor activity modifying protein 2 , galanin receptor 1, ataxin 1, LIM homeobox 1) in the aorta (Table 2 and Table 4) satisfying both our threshold (at least $\pm 0.90 \log _{2}$ ratio) and statistical significance $(p<0.05)$ 
criteria. More importantly, there was an agreement regarding gene expression in case of only one gene (taste receptor type 2 member 119) in these tissues (Table 2). Apart from this gene, we found only one additional transcript (indian hedgehog) whose expression was altered by nitrate treatment in both tissues, but the direction of change was the opposite in the heart and the aorta; that is, gene expression decreased in the heart and increased in the aorta (Table 2). Selected significant cDNA microarray changes were verified with QRT-PCR in the case of ten genes in the heart and five genes in the aorta (Tables 2, 3, and 4).

We also conducted additional QRT-PCR analysis of genes that were absent from the DNA microarray and may be important in relation to oxidative/nitrative/nitrosative stress. The outcome of this analysis confirmed the microarray results, indicating that the gene expression pattern was dissimilar in the heart and the aorta. Although the levels of two transcripts, nicotinamide adenine dinucleotide phosphate oxidase (NOX) 4 and nitric oxide synthase (NOS) 2 were elevated in both tissues, other changes were different (Table 5). For example, superoxide dismutase (SOD) 2 and SOD3 and matrix metalloproteinase (MMP) 2 expression were increased in the aorta, but not in the heart. Additionally, transcript levels of tissue inhibitor of MMP1 decreased in the aorta, with no change in the heart, while tissue inhibitor of MMP4 decreased in the heart and remained unaffected in the aorta.

The transcript levels of selected vascular signaling molecules were further investigated by QRT-PCR. There were no significant changes in expression of these selected genes (i.e. PDE1A, PDE2A2, AGTR1a, AGTR1b, GUCY1A2, GUCY1A3, GUCY1B2, GUCY1B3) in response to chronic nitroglycerin treatment (Supplementary Material 2.). 


\section{Discussion and conclusion}

In the present pharmacogenomic study, we demonstrated for the first time that the gene expression pattern in the heart and aorta remarkably differs in response to a nitroglycerin treatment that leads to the development of vascular nitrate tolerance. In our microarray analysis study, only one gene (taste receptor type 2 member 119) showed similar change in these tissues regarding the direction and magnitude of the alteration. Expression of only one other gene (indian hedgehog) was altered significantly but in an opposite direction in the heart and the aorta. All other genes showing significantly altered expression in the heart were unaffected in the aorta in response to a nitroglycerin treatment that leads to vascular nitrate tolerance. Furthermore, genes with altered expression in the aorta were not influenced in the heart. These data suggest that the repeated nitroglycerin treatment induces a tissuespecific response at the transcript level. The tissue-specific differences were further confirmed in our present study by demonstrating that repeated nitroglycerin treatment resulted in an increased NO content in the heart but not in the aorta.

The well-known cardioprotective effects of nitroglycerin, at least in part, are attributed to the drug's vasodilator function and consequent reduction of cardiac preload and afterload. Development of vascular tolerance with prolonged use, however, reduces the hemodynamic effectiveness of nitrate therapy. Nevertheless, nitroglycerin exerts a direct myocardial anti-ischemic effect that remains preserved, even in the state of vascular nitrate tolerance induced by chronic nitrate treatment $^{2,4,5,8}$, however, the underlying mechanisms of nitrate-induced cardioprotection are not entirely clear. To date, only two studies have investigated alterations of vascular gene expression in nitrate-tolerance ${ }^{13,14}$ along with one additional study having analyzed cardiac gene expression in response to a 4-day 
treatment with organic nitrates ${ }^{15}$. However, these studies are substantially different in comparison to our work, because they have only focused on either the aorta or the heart. Moreover, Wang et al. ${ }^{14}$ have applied a very short 8-hour nitroglycerin infusion, thereby allowing observations only of early changes following nitroglycerin treatment. Our present study is the first in the literature to conduct a parallel gene expression analysis in the heart and aorta in response to repeated nitroglycerin treatments that lead to the development of vascular nitrate tolerance. As our present study has revealed substantial tissue-specific differences in cardiac and aortic gene expression, it is plausible to conclude that these tissue-dependent genetic responses may partially account for the persistence of the cardioprotective effect of nitroglycerin observed in the state of vascular nitrate tolerance ${ }^{2}$ and thereby may contribute to a better understanding and advancement of the field of long-term nitrate therapy.

Results of our cDNA microarray analysis clearly showed that only two genes were altered significantly both in the heart and the aorta at the same time, in our present study. Expression of taste receptor type 2 member 119 was increased in both tissues, while the expression of indian hedgehog was decreased in the heart and increased in the aorta following nitroglycerin treatment. The G protein-coupled taste receptor type 2 is primarily found on the tongue playing a role in detection of a variety of nutrient compounds. It has been shown recently that the taste receptor type 2 is also expressed by the rodent and the human heart with a predicted nutrient sensor function ${ }^{16}$. Interestingly, taste receptor type 1 is suggested to inhibit autophagy by sensing extracellular amino acids in different tissues, including the heart ${ }^{17}$. In the vascular system taste receptor type 2 likely plays a role in regulation of vessel relaxation ${ }^{18}$. However, the precise role of cardiac and aortic taste receptors in the state of vascular nitrate tolerance remains to be elucidated. Indian hedgehog 
participates in development and angiogenesis ${ }^{19}$, but its role in the state of vascular nitrate tolerance needs to be identified.

Microarray analysis revealed several genes showing significantly altered expression only in the heart with no change in the aorta in response to nitroglycerin pretreatment that leads to vascular nitrate tolerance. Some of these genes have a clearly identified or suggested function in the heart. For instance, fibroblast growth factor receptor 1 plays a role in heart development ${ }^{20}$, postnatal cardiac remodeling ${ }^{21}$ and mediation of protection against ischemic stimuli ${ }^{22}$; potassium voltage-gated channels contribute to maintaining the resting membrane potential and restoring it after depolarization ${ }^{23}$; heat shock factor 1 is responsible for regulation of heat shock proteins $^{24}$; agrin modulates cardiomyocyte contraction ${ }^{25}$, and keratin may play a role in the rearrangement of desmoplakins into intercalated discs during the development of myocardium ${ }^{26}$. The exact role of these cardiac genes in the state of vascular nitrate tolerance induced by chronic nitroglycerin administration is not clear. In a large scale multi-center clinical study of 52,693 patients with acute coronary syndrome chronic nitrate therapy was associated with beneficial clinical presentation and smaller release of necrotic markers ${ }^{3}$, thus one may speculate that the increased expression of potassium voltage-gated channel subunits by chronic nitrate administration may improve the resistance of the heart against ischemia/reperfusion injury by shortening phase 3 repolarization and preventing cytosolic $\mathrm{Ca}^{2+}$ overload ${ }^{27}$. However, it has been also shown that nitroglycerin treatment leading to vascular nitrate tolerance interferes with the efficacy of myocardial pre- ${ }^{28}$ and postconditioning $^{9}$. Along with others we have previously shown that inducible Hsp70 (Hsp72) may play a role in ischemic tolerance ${ }^{29,30}$ and Hsp72 was implicated as a mediator of long-term cardioprotection ${ }^{31}$. Since in the present study heat shock 
factor 1, a positive regulator of $\mathrm{Hsp} 72$ was decreased, one may speculate that dysregulation of $\mathrm{HSF} 1 / \mathrm{Hsp} 72$ pathway in response to chronic nitrate treatment may interfere with cardioprotective mechanisms. The functional role of the other genes altered in our present study (e.g. Prpg1, Haus1, Vipr1) is not yet elucidated in cardiac physiology and their relations to treatment with NO-donors have not been shown.

In our current study, we also showed several genes that were influenced exclusively in the aorta and were not altered in the heart in response to nitroglycerin treatment. Only a small percentage of these genes were shown to have a specific function in the vascular system. For example, tubulin plays a role in shear stressmediated regulation of vessel tone ${ }^{32}$; ras-related associated with diabetes GTPbinding protein inhibits vascular lesion formation ${ }^{33}$; and receptor activity-modifying protein 2 contributes to adrenomedullin-induced vasorelaxation ${ }^{34}$. However, to the best of our knowledge, these genes were not yet described in connection with nitrate tolerance. Possible specific function of other genes altered in our present study (e.g. Usp15, Npm1, Wfdc2) has not yet been identified in the aorta.

The metabolism of nitroglycerin was proposed to increase production of reactive oxygen intermediates $(\mathrm{ROI})^{35}$. Moreover, $\mathrm{ROIs}$ are able to induce diverse cellular mechanisms that may possibly contribute to the development of vascular nitrate tolerance ${ }^{1}$ or direct nitroglycerin-induced cardioprotection ${ }^{36}$. Therefore, we performed additional QRT-PCR analysis of genes that are related to oxidative and nitrative/nitrosative stress. These tests also confirmed our initial hypothesis, indicating that the gene expression pattern was dissimilar in the heart and the aorta. Importantly, transcript levels of the predominant vascular NADPH oxidase isoform, NOX4, as well as SOD2 and SOD3 were increased in the aorta, likely reflecting an 
augmented superoxide production in the state of nitrate tolerance. Moreover, MMP2 was also elevated in the aorta, suggesting an increased oxidative stress, as ROI derived from either NOX activity or metabolism of nitroglycerin are likely involved in the expression of $\mathrm{MMPs}^{37}$. In our present study, the expression of NOX4 gene also increased in the heart in response to chronic nitrate treatment. However, the transcript level of SODs and MMPs were not altered and because the SOD enzymes are under transcriptional regulation by $\mathrm{ROIs}^{38}$, we conclude that nitroglycerin treatment did not result in oxidative stress in the myocardium, especially when compared to the aorta. This notion is in agreement with our previous results, indicating that vascular nitrate tolerance does not trigger oxidative stress in the heart $^{8}$. In addition, the cardiac effects of NOX4 are controversial in the literature, both beneficial and deleterious effects have been indicated ${ }^{39,40}$. Furthermore, the predominant isoform in the adult heart is $\mathrm{NOX} 2^{37}$, whose expression remained unchanged in our study. These results, with their recognized limitations, tend to support the conclusion that free radical generation plays a role in the vascular effects of nitrate tolerance, however, in agreement with previous findings, vascular nitrate tolerance does not seem to result in increased oxidative and nitrative/nitrosative stress in the heart.

In conclusion, this is the first pharmacogenomic analysis demonstrating that the heart and the aorta differentially respond to nitroglycerin treatment that causes vascular nitrate tolerance. Our findings may contribute to a better understanding of the Janus-faced nature of nitroglycerin, which is characterized by anti-anginal and direct cardioprotective effects, as well as development of tolerance and vascular dysfunction. We hope that our findings may help to open up novel directions in rational pharmacological design or development of drug combinations to prevent 
tolerance development and facilitate cardioprotective effects of NO-donor molecules. Further research is needed to confirm our results in other models of nitrate tolerance, and to elucidate the exact role of differentially expressed genes in nitrate tolerance and nitrate-induced cardioprotection.

Conflict of interest: Nothing to declare.

Acknowledgements: We are grateful to Dr. Gábor Szénási for kindly donating nitroglycerin for the present study, as well as to Anthony Hernandes for proofreading the manuscript. We acknowledge the support of grants from the Hungarian Scientific Research Fund (K79167), the National Office for Research and Technology (JedlikMed-Food-2008), and the European Social Fund (TÁMOP-4.2.2.A-11/1/KONV-20120035). This work was also supported by the János Bolyai Research Scholarship of the Hungarian Academy of Sciences (TC). PF is a Szentágothai Fellow of the Hungarian National Program of Excellence (TÁMOP 4.2.4.A/2-11-1-2012-0001).

\section{References:}

1. Munzel T, Daiber A, Gori T. Nitrate therapy: new aspects concerning molecular action and tolerance. Circulation. 2011 May 17;123(19):2132-44.

2. Csont T, Ferdinandy P. Cardioprotective effects of glyceryl trinitrate: beyond vascular nitrate tolerance. Pharmacol Ther. 2005 Jan;105(1):57-68.

3. Ambrosio G, Del Pinto M, Tritto I, Agnelli G, Bentivoglio M, Zuchi C, Anderson FA, Gore JM, Lopez-Sendon J, Wyman A, Kennelly BM, Fox KA, Investigators G. Chronic nitrate therapy is associated with different presentation and evolution of acute coronary syndromes: insights from 52,693 patients in the Global Registry of Acute Coronary Events. Eur Heart J. 2010 Feb;31(4):430-8.

4. Csont T, Szilvassy Z, Fulop F, Nedeianu S, Pali T, Tosaki A, Dux L, Ferdinandy P. Direct myocardial anti-ischaemic effect of GTN in both nitrate-tolerant 
and nontolerant rats: a cyclic GMP-independent activation of KATP. Br J Pharmacol. 1999 Dec;128(7):1427-34.

5. Ferdinandy P, Szilvassy Z, Csont T, Csonka C, Nagy E, Koltai M, Dux L. Nitroglycerin-induced direct protection of the ischaemic myocardium in isolated working hearts of rats with vascular tolerance to nitroglycerin. $\mathrm{Br} J$ Pharmacol. 1995 Aug;115(7):1129-31.

6. Hill M, Takano H, Tang XL, Kodani E, Shirk G, Bolli R. Nitroglycerin induces late preconditioning against myocardial infarction in conscious rabbits despite development of nitrate tolerance. Circulation. 2001 Aug 7;104(6):694-9.

7. Csont T, Pali T, Szilvassy Z, Ferdinandy P. Lack of correlation between myocardial nitric oxide and cyclic guanosine monophosphate content in both nitratetolerant and -nontolerant rats. Biochem Pharmacol. 1998 Nov 1;56(9):1139-44.

8. Csont T, Csonk AC, Onody A, Gorbe A, Dux L, Schulz R, Baxter GF, Ferdinandy $P$. Nitrate tolerance does not increase production of peroxynitrite in the heart. Am J Physiol Heart Circ Physiol. 2002 Jul;283(1):H69-76.

9. Fekete V, Murlasits Z, Aypar E, Bencsik P, Sarkozy M, Szenasi G, Ferdinandy P, Csont T. Myocardial postconditioning is lost in vascular nitrate tolerance. $J$ Cardiovasc Pharmacol. 2013 Sep;62(3):298-303.

10. Csont T, Csonka C, Kovacs P, Jancso G, Ferdinandy P. Capsaicin-sensitive sensory neurons regulate myocardial nitric oxide and cGMP signaling. Eur $J$ Pharmacol. 2003 Aug 22;476(1-2):107-13.

11. Palotas M, Palotas A, Puskas LG, Kitajka K, Pakaski M, Janka Z, Molnar J, Penke B, Kalman J. Gene expression profile analysis of the rat cortex following treatment with imipramine and citalopram. Int J Neuropsychopharmacol. 2004 Dec;7(4):401-13. 
12. Puskas LG, Bereczki E, Santha M, Vigh L, Csanadi G, Spener F, Ferdinandy P, Onochy A, Kitajka K. Cholesterol and cholesterol plus DHA diet-induced gene expression and fatty acid changes in mouse eye and brain. Biochimie. 2004 Nov;86(11):817-24.

13. Pi X, Yan C, Kim D, Chen J, Berk BC. Differential expression of genes from nitrate-tolerant rat aorta. J Vasc Res. 2002 Jul-Aug;39(4):304-10.

14. Wang EQ, Lee WI, Brazeau D, Fung HL. cDNA microarray analysis of vascular gene expression after nitric oxide donor infusions in rats: implications for nitrate tolerance mechanisms. AAPS PharmSci. 2002;4(2):E10.

15. Pautz A, Rauschkolb P, Schmidt N, Art J, Oelze M, Wenzel P, Forstermann U, Daiber A, Kleinert $\mathrm{H}$. Effects of nitroglycerin or pentaerithrityl tetranitrate treatment on the gene expression in rat hearts: evidence for cardiotoxic and cardioprotective effects. Physiol Genomics. 2009 Jul 9;38(2):176-85.

16. Foster SR, Porrello ER, Purdue B, Chan HW, Voigt A, Frenzel S, Hannan RD, Moritz KM, Simmons DG, Molenaar P, Roura E, Boehm U, Meyerhof W, Thomas WG. Expression, regulation and putative nutrient-sensing function of taste GPCRs in the heart. PLoS One. 2013;8(5):e64579.

17. Wauson EM, Zaganjor E, Cobb $\mathrm{MH}$. Amino acid regulation of autophagy through the GPCR TAS1R1-TAS1R3. Autophagy. 2013 Mar;9(3):418-9.

18. Manson ML, Dahlen SE, Adner M. Characterization Of Relaxations Of The Guinea Pig Aorta In Response To Bitter Taste Receptor Agonists. 2012. Available at: http://www.pa2online.org/abstract/abstract.jsp?abid=30927. Accessed 17/02/2014 2014.

19. Varjosalo M, Taipale J. Hedgehog: functions and mechanisms. Genes Dev. 2008 Sep 15;22(18):2454-72. 
20. Dell'Era P, Ronca R, Coco L, Nicoli S, Metra M, Presta M. Fibroblast growth factor receptor-1 is essential for in vitro cardiomyocyte development. Circ Res. 2003 Sep 5;93(5):414-20.

21. Cilvik SN, Wang JI, Lavine KJ, Uchida K, Castro A, Gierasch CM, Weinheimer CJ, House SL, Kovacs A, Nichols CG, Ornitz DM. Fibroblast growth factor receptor 1 signaling in adult cardiomyocytes increases contractility and results in a hypertrophic cardiomyopathy. PLoS One. 2013;8(12):e82979.

22. Liu SQ, Roberts D, Kharitonenkov A, Zhang B, Hanson SM, Li YC, Zhang LQ, $\mathrm{Wu} \mathrm{YH}$. Endocrine protection of ischemic myocardium by FGF21 from the liver and adipose tissue. Sci Rep. 2013;3:2767.

23. Snyders DJ. Structure and function of cardiac potassium channels. Cardiovasc Res. 1999 May;42(2):377-90.

24. Latchman DS. Heat shock proteins and cardiac protection. Cardiovasc Res. 2001 Sep;51(4):637-46.

25. Hilgenberg LG, Pham B, Ortega M, Walid S, Kemmerly T, O'Dowd DK, Smith MA. Agrin regulation of alpha3 sodium-potassium ATPase activity modulates cardiac myocyte contraction. J Biol Chem. 2009 Jun 19;284(25):16956-65.

26. van der Loop FT, Schaart G, Langmann H, Ramaekers FC, Viebahn C. Rearrangement of intercellular junctions and cytoskeletal proteins during rabbit myocardium development. Eur J Cell Biol. 1995 Sep;68(1):62-9.

27. Gross GJ, Peart JN. KATP channels and myocardial preconditioning: an update. Am J Physiol Heart Circ Physiol. 2003 Sep;285(3):H921-30.

28. Szilvassy Z, Ferdinandy P, Nagy I, Jakab I, Koltai M. The effect of continuous versus intermittent treatment with transdermal nitroglycerin on pacing-induced preconditioning in conscious rabbits. Br J Pharmacol. 1997 Jun;121(3):491-6. 
29. Csont T, Balogh G, Csonka C, Boros I, Horvath I, Vigh L, Ferdinandy P. Hyperlipidemia induced by high cholesterol diet inhibits heat shock response in rat hearts. Biochem Biophys Res Commun. 2002 Feb 8;290(5):1535-8.

30. Mestril R, Dillmann WH. Heat shock proteins and protection against myocardial ischemia. J Mol Cell Cardiol. 1995 Jan;27(1):45-52.

31. Marber MS, Latchman DS, Walker JM, Yellon DM. Cardiac stress protein elevation 24 hours after brief ischemia or heat stress is associated with resistance to myocardial infarction. Circulation. 1993 Sep;88(3):1264-72.

32. Hutcheson IR, Griffith TM. Mechanotransduction through the endothelial cytoskeleton: mediation of flow- but not agonist-induced EDRF release. $\mathrm{Br} J$ Pharmacol. 1996 Jun;118(3):720-6.

33. Fu M, Zhang J, Tseng YH, Cui T, Zhu X, Xiao Y, Mou Y, De Leon H, Chang MM, Hamamori Y, Kahn CR, Chen YE. Rad GTPase attenuates vascular lesion formation by inhibition of vascular smooth muscle cell migration. Circulation. 2005 Mar 1;111(8):1071-7.

34. Tam CW, Husmann K, Clark NC, Clark JE, Lazar Z, Ittner LM, Gotz J, Douglas G, Grant AD, Sugden D, Poston L, Poston R, McFadzean I, Marber MS, Fischer JA, Born W, Brain SD. Enhanced vascular responses to adrenomedullin in mice overexpressing receptor-activity-modifying protein 2. Circ Res. 2006 Feb 3;98(2):262-70.

35. Sydow K, Daiber A, Oelze M, Chen Z, August M, Wendt M, Ullrich V, Mulsch A, Schulz E, Keaney JF, Jr., Stamler JS, Munzel T. Central role of mitochondrial aldehyde dehydrogenase and reactive oxygen species in nitroglycerin tolerance and cross-tolerance. J Clin Invest. 2004 Feb;113(3):482-9. 
36. Costa AD, Garlid KD. Intramitochondrial signaling: interactions among mitoKATP, PKCepsilon, ROS, and MPT. Am J Physiol Heart Circ Physiol. 2008 Aug;295(2):H874-82.

37. Bedard K, Krause $\mathrm{KH}$. The NOX family of ROS-generating NADPH oxidases: physiology and pathophysiology. Physiol Rev. 2007 Jan;87(1):245-313.

38. Miao L, St Clair DK. Regulation of superoxide dismutase genes: implications in disease. Free Radic Biol Med. 2009 Aug 15;47(4):344-56.

39. Sciarretta S, Zhai P, Shao D, Zablocki D, Nagarajan N, Terada LS, Volpe M, Sadoshima J. Activation of NADPH oxidase 4 in the endoplasmic reticulum promotes cardiomyocyte autophagy and survival during energy stress through the protein kinase RNA-activated-like endoplasmic reticulum kinase/eukaryotic initiation factor 2alpha/activating transcription factor 4 pathway. Circ Res. 2013 Nov 8;113(11):125364.

40. Varga ZV, Kupai K, Szucs G, Gaspar R, Paloczi J, Farago N, Zvara A, Puskas LG, Razga Z, Tiszlavicz L, Bencsik P, Gorbe A, Csonka C, Ferdinandy P, Csont T. MicroRNA-25-dependent up-regulation of NADPH oxidase 4 (NOX4) mediates hypercholesterolemia-induced oxidative/nitrative stress and subsequent dysfunction in the heart. J Mol Cell Cardiol. 2013 Sep;62:111-21. 


\section{Figure legends}

Figure 1. Experimental protocol. Male Wistar rats were given subcutaneously nitroglycerin to induce vascular nitrate tolerance or its vehicle 3 times a day for 3 days. On the fourth day hearts and aortas were isolated for DNA microarray analysis ( $n=8$ in each group), and the development of vascular tolerance to nitroglycerin was confirmed in a subgroup ( $\mathrm{n}=4$ in each group) of animals in vivo.

Figure 2. Validation of the development of vascular nitrate tolerance. Values represent mean arterial blood pressure following intravenous injection of increasing doses of nitroglycerin. Results are expressed as mean \pm S.E.M. \#p $<0.05$ vs. baseline, ${ }^{*} p<0.05$ vs. corresponding nitrate-tolerant group ( $n=4$ in each group).

Figure 3. Cardiac and aortic NO content. The effect of systemic nitroglycerin pretreatment leading to vascular nitrate tolerance on cardiac and vascular nitric oxide (NO) content measured by electron paramagnetic resonance spectroscopy (EPR) after in vivo spin trapping. Results are expressed as mean \pm S.E.M. ${ }^{*} p<0.05$ vs. non-tolerant group ( $\mathrm{n}=4$ in each group). 
Figure 1.

Non-tolerant group

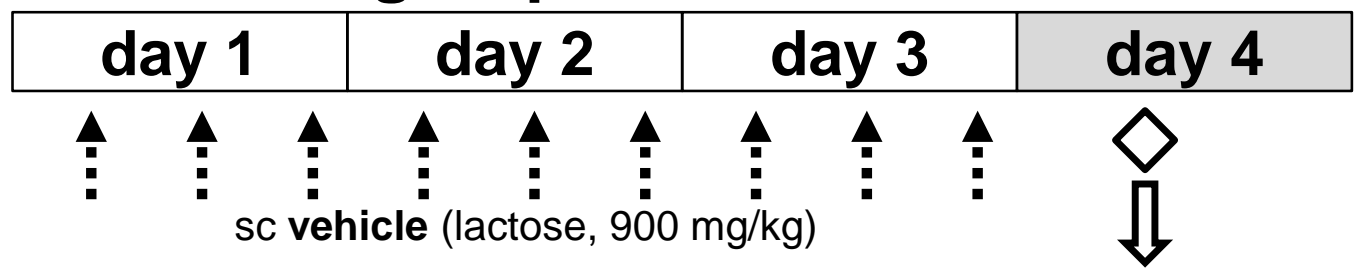

Nitrate-tolerant group

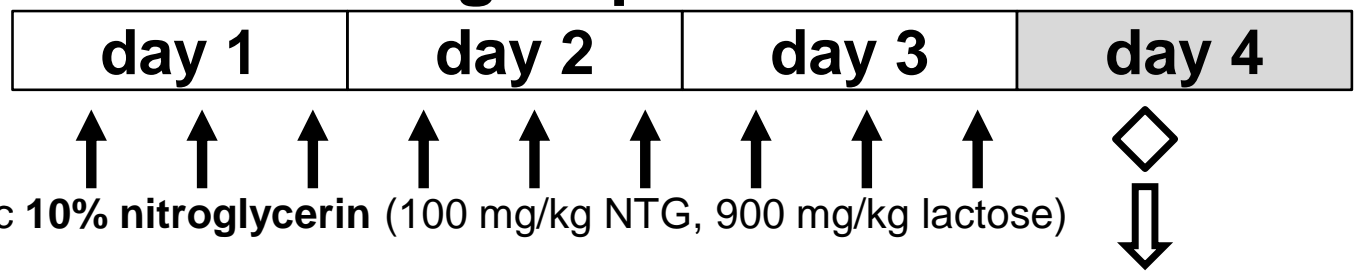

$\checkmark$ in vivo validation of the development of vascular nitrate tolerance

$\boldsymbol{\eta}$ isolation of heart and aorta for DNA microarray 
Figure 2.

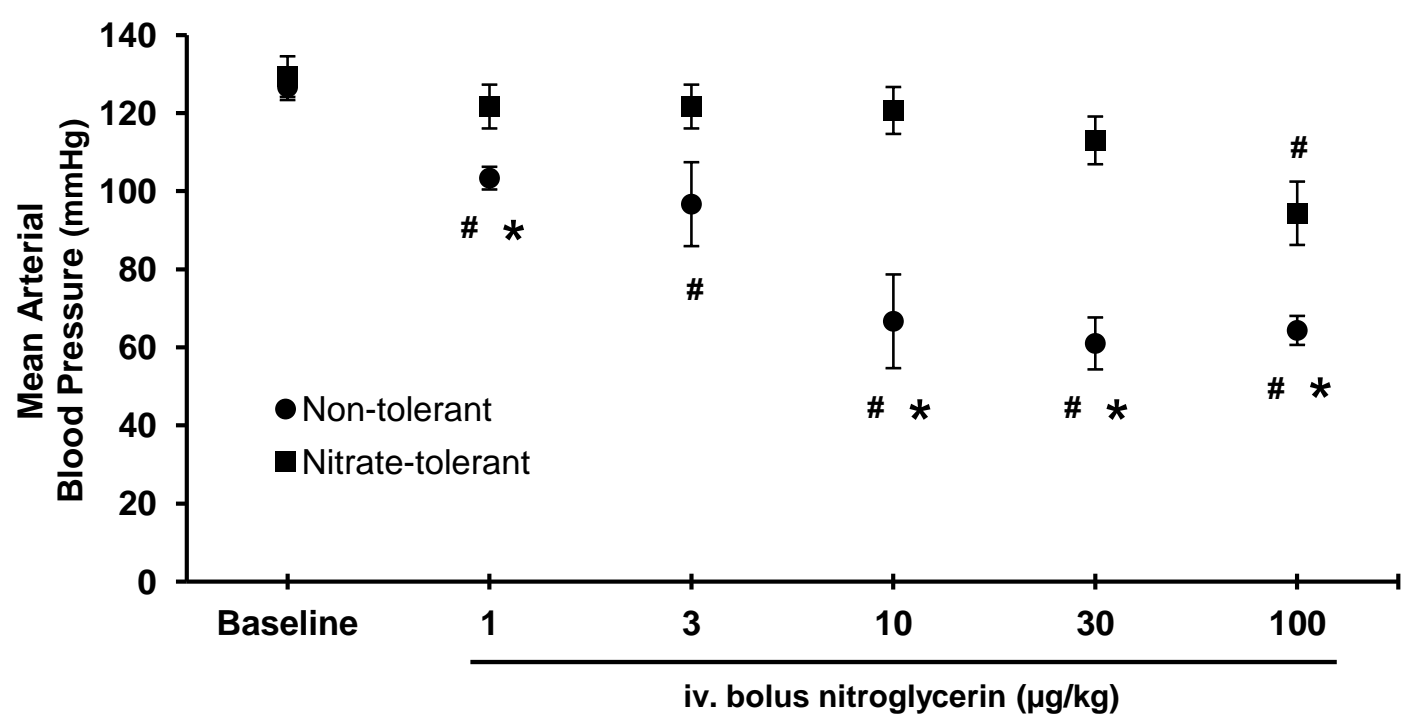


Figure 3.

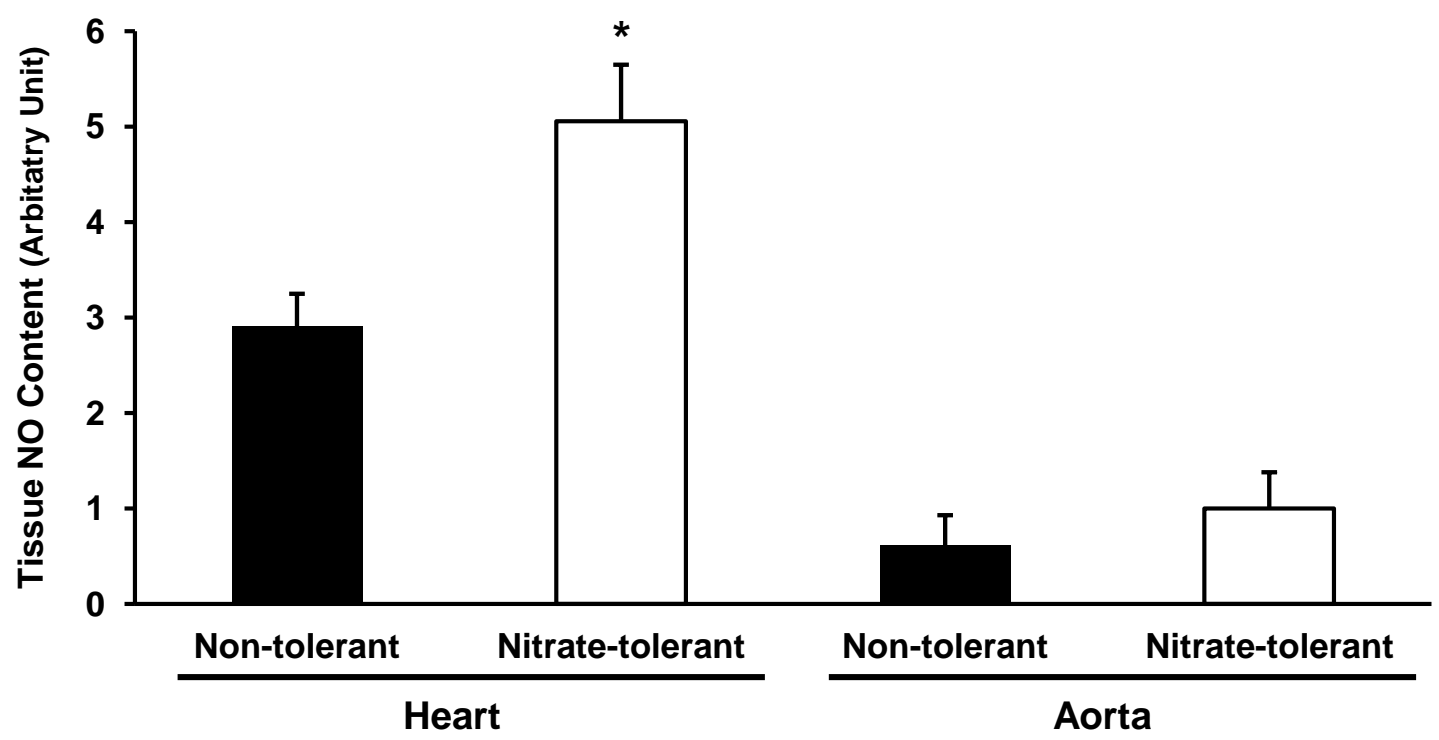


Table 1. Morphological and ex vivo hemodynamic parameters.

Non-tolerant

Body Weight (g)

Heart Weight $(\mathrm{g})$

Heart Rate (bpm)

Coronary Flow (mL/min)
$320 \pm 10$

$1.2 \pm 0.1$

$300 \pm 11$

$15 \pm 1$
Nitrate-tolerant $320 \pm 8$

$1.3 \pm 0.1$

$320 \pm 9$

$15 \pm 2$

Results are expressed as mean \pm S.E.M. 
Table 2. Results of DNA microarray analysis showing genes with significantly altered expression both in the heart and aorta in response to chronic nitroglycerin pretreatment.

\begin{tabular}{|c|c|c|c|c|c|c|c|c|}
\cline { 4 - 8 } \multicolumn{2}{c|}{} & \multicolumn{3}{c|}{ Heart } & \multicolumn{3}{c|}{ Aorta } \\
\hline $\begin{array}{c}\text { Gene } \\
\text { Function }\end{array}$ & $\begin{array}{c}\text { Gene Name } \\
\text { provided by } R G D^{a}\end{array}$ & $\begin{array}{c}\text { Accession } \\
\text { Number } \\
\text { Gene Symbol }\end{array}$ & $\begin{array}{c}\text { Log }_{2} \\
(\text { SD })\end{array}$ & $\begin{array}{c}\text { Fold } \\
\text { Change }\end{array}$ & $\begin{array}{c}\text { QRT-PCR } \\
\text { Log }_{2} \text { (SD) } \\
\text { Confirmed }\end{array}$ & $\begin{array}{c}\text { Log }_{2} \\
\text { (SD) }\end{array}$ & $\begin{array}{c}\text { Fold } \\
\text { Change }\end{array}$ & $\begin{array}{c}\text { QRT-PCR } \\
\text { Log } \\
\text { Confirmed }\end{array}$ \\
\hline $\begin{array}{c}\text { Signal } \\
\text { transduction }\end{array}$ & $\begin{array}{c}\text { taste receptor, type 2, } \\
\text { member } 119\end{array}$ & $\begin{array}{c}\text { AF227140 } \\
\text { Tas2r119 }\end{array}$ & $\begin{array}{c}1.83 \\
(0.78)\end{array}$ & 3.56 & $\begin{array}{c}1.63(0.43) \\
\text { YES }\end{array}$ & $\begin{array}{c}1.75 \\
(0.07)\end{array}$ & $\begin{array}{c}3.38 \\
1.58(0.04) \\
\text { YES }\end{array}$ \\
\hline development & indian hedgehog & $\begin{array}{c}\text { AF162914 } \\
\text { Ihh }\end{array}$ & $\begin{array}{c}-0.94 \\
(0.33)\end{array}$ & -1.92 & $\begin{array}{c}-1.22(0.01) \\
\text { YES }\end{array}$ & $\begin{array}{c}0.99 \\
(0.03)\end{array}$ & $\begin{array}{c}1.98 \\
1.26(0.16) \\
\text { YES }\end{array}$ \\
\hline
\end{tabular}

Values show gene expression in organs of nitrate-tolerant vs. non-tolerant rats. $\log _{2}$ ratio reaching at least \pm 0.90 and $p<0.05$ were considered as significant alterations. Altered gene expressions were confirmed by QRT-PCR.

${ }^{a} \mathrm{RGD}$ : rat genome database 
Table 3. Results of DNA microarray analysis showing genes with significantly altered expression only in the heart in response to chronic nitroglycerin pretreatment.

\begin{tabular}{|c|c|c|c|c|c|c|c|c|}
\hline & & & & & & & & \\
\hline \multirow[b]{2}{*}{$\begin{array}{c}\text { Gene } \\
\text { Function }\end{array}$} & \multirow[b]{2}{*}{$\begin{array}{c}\text { Gene Name } \\
\text { provided by } R G D^{a}\end{array}$} & \multirow[b]{2}{*}{$\begin{array}{c}\text { Accession } \\
\text { Number } \\
\text { Gene Symbol }\end{array}$} & \multicolumn{3}{|c|}{ Heart } & \multicolumn{3}{|c|}{ Aorta } \\
\hline & & & $\begin{array}{l}\log _{2} \\
(\mathrm{SD})\end{array}$ & $\begin{array}{c}\text { Fold } \\
\text { Change }\end{array}$ & \begin{tabular}{l|} 
QRT-PCR \\
Log $_{2}$ (SD) \\
Confirmed
\end{tabular} & $\begin{array}{l}\log _{2} \\
\text { (SD) }\end{array}$ & $\begin{array}{c}\text { Fold } \\
\text { Change }\end{array}$ & $\begin{array}{l}\text { QRT-PCR } \\
\text { Log }_{2} \text { (SD) } \\
\text { Confirmed }\end{array}$ \\
\hline $\begin{array}{c}\text { cell } \\
\text { proliferation }\end{array}$ & $\begin{array}{c}\text { fibroblast growth factor } \\
\text { receptor } 1\end{array}$ & $\begin{array}{c}\text { D12498 } \\
\text { Fgfr1 } \\
\end{array}$ & $\begin{array}{l}-0.97 \\
(0.08) \\
\end{array}$ & -1.96 & \begin{tabular}{|c|}
$-1.21(0.61)$ \\
YES
\end{tabular} & $\begin{array}{c}-0.65 \\
(-)\end{array}$ & -1.57 & $\begin{array}{c}0.35(0.13) \\
\text { YES }\end{array}$ \\
\hline \multirow{3}{*}{$\begin{array}{l}\text { cell shape, } \\
\text { structure }\end{array}$} & $\begin{array}{c}\text { microtubule-associated } \\
\text { protein } 6 \\
\end{array}$ & $\begin{array}{c}\text { NM_017204 } \\
\text { Map6 }\end{array}$ & $\begin{array}{c}1.03 \\
(0.06) \\
\end{array}$ & 2.05 & \begin{tabular}{|c|}
$1.02(0.81)$ \\
YES \\
\end{tabular} & n.d. $^{b}$ & n.d. & $\begin{array}{c}4.65(0.68) \\
- \\
\end{array}$ \\
\hline & crystallin, gamma E & $\begin{array}{c}\text { J00716 } \\
\text { Cryge }\end{array}$ & $\begin{array}{l}-1.03 \\
(0.50) \\
\end{array}$ & -2.04 & - & $\begin{array}{l}0.10 \\
(0.34) \\
\end{array}$ & 1.07 & - \\
\hline & keratin 9 & $\begin{array}{c}\text { NM_153476 } \\
\text { Krt9 } \\
\end{array}$ & $\begin{array}{l}-0.97 \\
(0.36)\end{array}$ & -1.96 & \begin{tabular}{|c|}
$-1.21(0.19)$ \\
YES
\end{tabular} & $\begin{array}{l}-0.22 \\
(0.34) \\
\end{array}$ & -1.16 & $\begin{array}{c}-0.9(0.24) \\
\text { NO }\end{array}$ \\
\hline $\begin{array}{l}\text { contraction } \\
\text { regulation }\end{array}$ & agrin & $\begin{array}{l}\text { M64780 } \\
\text { Agrn }\end{array}$ & $\begin{array}{l}-1.35 \\
(0.14)\end{array}$ & -2.54 & \begin{tabular}{|c|}
$-0.11(0.7)$ \\
NO
\end{tabular} & n.d. & n.d. & $\begin{array}{c}0.49(0.17) \\
\text { YES }\end{array}$ \\
\hline \multirow{4}{*}{$\begin{array}{l}\text { inflammatory } \\
\text { response }\end{array}$} & $\begin{array}{l}\text { CD59 molecule, } \\
\text { complement regulatory } \\
\text { protein }\end{array}$ & $\begin{array}{l}\text { NM_012925 } \\
\text { Cd59 }\end{array}$ & $\begin{array}{l}0.97 \\
(0.09)\end{array}$ & 1.96 & $\begin{array}{c}1.21(0.26) \\
\text { YES }\end{array}$ & $\begin{array}{l}-0.62 \\
(0.40)\end{array}$ & -1.54 & $\begin{array}{l}0.32(0.05) \\
\text { YES }\end{array}$ \\
\hline & $\begin{array}{c}\text { complement component } \\
4 \text { binding protein, beta }\end{array}$ & $\begin{array}{c}\text { NM_016995 } \\
\text { C4bpb }\end{array}$ & $\begin{array}{l}-1.40 \\
(0.11) \\
\end{array}$ & -2.64 & \begin{tabular}{|c|}
$-0.18(0.05)$ \\
NO
\end{tabular} & n.d. & n.d. & $\begin{array}{c}0.54(0.72) \\
- \\
\end{array}$ \\
\hline & $\begin{array}{l}\text { Fc fragment of IgE, high } \\
\text { affinity I, receptor for } \\
\text { alpha polypeptide }\end{array}$ & $\begin{array}{c}\text { NM_012724 } \\
\text { Fcer1a }\end{array}$ & $\begin{array}{l}-1.72 \\
(0.17)\end{array}$ & -3.30 & - & n.d. & n.d. & - \\
\hline & $\begin{array}{c}\text { colony stimulating factor } 3 \\
\text { (granulocyte) }\end{array}$ & $\begin{array}{c}\text { NM_017104 } \\
\text { Csf3 }\end{array}$ & $\begin{array}{l}-1.77 \\
(0.01) \\
\end{array}$ & -3.42 & - & $\begin{array}{l}-0.09 \\
(0.47) \\
\end{array}$ & -1.06 & - \\
\hline \multirow[b]{2}{*}{ metabolism } & $\begin{array}{c}\text { hydroxysteroid (17-beta) } \\
\text { dehydrogenase } 11\end{array}$ & $\begin{array}{l}\text { BQ202947 } \\
\text { Hsd17b11 }\end{array}$ & $\begin{array}{l}-1.53 \\
(0.42) \\
\end{array}$ & -2.88 & - & $\begin{array}{l}-0.71 \\
(0.39) \\
\end{array}$ & -1.64 & - \\
\hline & $\begin{array}{l}\text { hydroxysteroid 11-beta } \\
\text { dehydrogenase } 2\end{array}$ & $\begin{array}{l}\text { NM_017081 } \\
\text { Hsd11b2 }\end{array}$ & $\begin{array}{l}-0.99 \\
(0.05) \\
\end{array}$ & -1.99 & $\begin{array}{c}-1.14(0.05) \\
\text { YES } \\
\end{array}$ & $\begin{array}{l}0.37 \\
(0.19) \\
\end{array}$ & 1.29 & $\begin{array}{c}2.01(0.28) \\
\text { NO }\end{array}$ \\
\hline \multirow{2}{*}{$\begin{array}{l}\text { potassium } \\
\text { transport }\end{array}$} & $\begin{array}{c}\text { potassium voltage-gated } \\
\text { channel, subfamily H, } \\
\text { member } 2\end{array}$ & $\begin{array}{l}\text { U75210 } \\
\text { Kcnh2 }\end{array}$ & $\begin{array}{c}0.90 \\
(0.06)\end{array}$ & 1.87 & $\begin{array}{c}1.23(0.48) \\
\text { YES }\end{array}$ & $\begin{array}{c}-0.17 \\
(-)\end{array}$ & -1.13 & $\begin{array}{c}0.61(0.09) \\
\text { YES }\end{array}$ \\
\hline & $\begin{array}{c}\text { potassium voltage-gated } \\
\text { channel, subfamily H, } \\
\text { member } 3 \\
\end{array}$ & $\begin{array}{c}\mathrm{NM}_{\bar{K}} 017108 \\
\mathrm{~K} c n h 3\end{array}$ & $\begin{array}{l}3.30 \\
(0.75)\end{array}$ & 9.85 & $\begin{array}{c}1.29(0.22) \\
\text { YES }\end{array}$ & $\begin{array}{l}-0.62 \\
(0.35)\end{array}$ & -1.53 & $\begin{array}{l}0.7(0.78) \\
\text { YES }\end{array}$ \\
\hline \multirow{2}{*}{ proteolysis } & $\begin{array}{l}\text { SUMO1/sentrin specific } \\
\text { peptidase } 6\end{array}$ & $\begin{array}{c}\text { XM_217209 } \\
\text { Senp6 }\end{array}$ & $\begin{array}{c}0.99 \\
(0.04)\end{array}$ & 1.98 & - & n.d. & n.d. & - \\
\hline & mast cell protease 1 & $\begin{array}{l}\text { U67915 } \\
\text { Mcpt1 }\end{array}$ & $\begin{array}{c}0.97 \\
(0.33)\end{array}$ & 1.96 & $\begin{array}{c}0.27(0.43) \\
\text { NO }\end{array}$ & $\begin{array}{c}0.40 \\
(0.03)\end{array}$ & 1.32 & $\begin{array}{c}-0.24(0.53) \\
\text { YES }\end{array}$ \\
\hline \multirow{7}{*}{$\begin{array}{c}\text { signal } \\
\text { transduction }\end{array}$} & catenin, beta like 1 & $\begin{array}{c}\text { NM_001024870 } \\
\text { Ctnnb/1 }\end{array}$ & $\begin{array}{l}-1.03 \\
(0.10)\end{array}$ & -2.04 & - & $\begin{array}{c}0.07 \\
(0.63)\end{array}$ & 1.05 & - \\
\hline & $\begin{array}{c}\text { proline-rich } \\
\text { proteoglycan } 1\end{array}$ & $\begin{array}{c}\text { K02247 } \\
\text { Prpg1 }\end{array}$ & $\begin{array}{l}-1.89 \\
(0.21) \\
\end{array}$ & -3.70 & - & n.d. & n.d. & - \\
\hline & $\begin{array}{c}\text { thyroid stimulating } \\
\text { hormone, beta }\end{array}$ & $\begin{array}{c}\text { NM_013116 } \\
\text { Tshb }\end{array}$ & $\begin{array}{c}1.10 \\
(0.43) \\
\end{array}$ & 2.15 & $\begin{array}{c}0.39(0.33) \\
\text { NO }\end{array}$ & n.d. & n.d. & $\begin{array}{c}0.44(0.19) \\
-\end{array}$ \\
\hline & $\begin{array}{l}\text { HAUS augmin-like } \\
\text { complex, subunit } 1\end{array}$ & $\begin{array}{c}\text { AF092207 } \\
\text { Haus1 }\end{array}$ & $\begin{array}{l}1.08 \\
(0.09) \\
\end{array}$ & 2.11 & \begin{tabular}{|c|}
$-0.27(0.11)$ \\
NO \\
\end{tabular} & n.d. & n.d. & $\begin{array}{c}-0.14(0.31) \\
- \\
\end{array}$ \\
\hline & $\begin{array}{l}\text { vasoactive intestinal } \\
\text { peptide receptor } 1\end{array}$ & $\begin{array}{c}\text { NM_012685 } \\
\text { Vipr1 } \\
\end{array}$ & $\begin{array}{l}0.97 \\
(0.01) \\
\end{array}$ & 1.96 & \begin{tabular}{|c|}
$0.96(0.41)$ \\
YES
\end{tabular} & $\begin{array}{c}-0.06 \\
(-) \\
\end{array}$ & -1.04 & $\begin{array}{c}-0.38(0.12) \\
\text { YES }\end{array}$ \\
\hline & $\begin{array}{c}\text { leucine rich repeat } \\
\text { neuronal } 3\end{array}$ & $\begin{array}{l}\text { AF291437 } \\
\text { Lrrn3 }\end{array}$ & $\begin{array}{c}0.96 \\
(0.02) \\
\end{array}$ & 1.94 & - & $\begin{array}{c}0.29 \\
(0.24) \\
\end{array}$ & 1.22 & - \\
\hline & $\begin{array}{c}\text { leukemia inhibitory factor } \\
\text { receptor alpha }\end{array}$ & $\begin{array}{l}\text { D86345 } \\
\text { Lifr }\end{array}$ & $\begin{array}{l}0.99 \\
(0.28)\end{array}$ & 1.98 & $\begin{array}{c}0.32(0.44) \\
\text { NO }\end{array}$ & n.d. & n.d. & $\begin{array}{c}0.02(0.31) \\
-\end{array}$ \\
\hline & $\begin{array}{c}\text { heat shock } \\
\text { transcription factor } 1\end{array}$ & $\begin{array}{c}\mathrm{X} 83094 \\
\text { Hsf1 }\end{array}$ & $\begin{array}{l}-1.29 \\
(0.06)\end{array}$ & -2.44 & - & n.d. & n.d. & - \\
\hline
\end{tabular}

Values show gene expression in organs of nitrate-tolerant vs. non-tolerant rats. $\log _{2}$ ratio reaching at least \pm 0.90 and $p<0.05$ were considered as significant alterations. Altered expression of selected genes was confirmed by QRT-PCR.

${ }^{a}$ RGD: rat genome database

${ }^{b}$ n.d.: not detectable 
Table 4. Results of DNA microarray analysis showing genes with significantly altered expression only in the aorta in response to chronic nitroglycerin pretreatment.

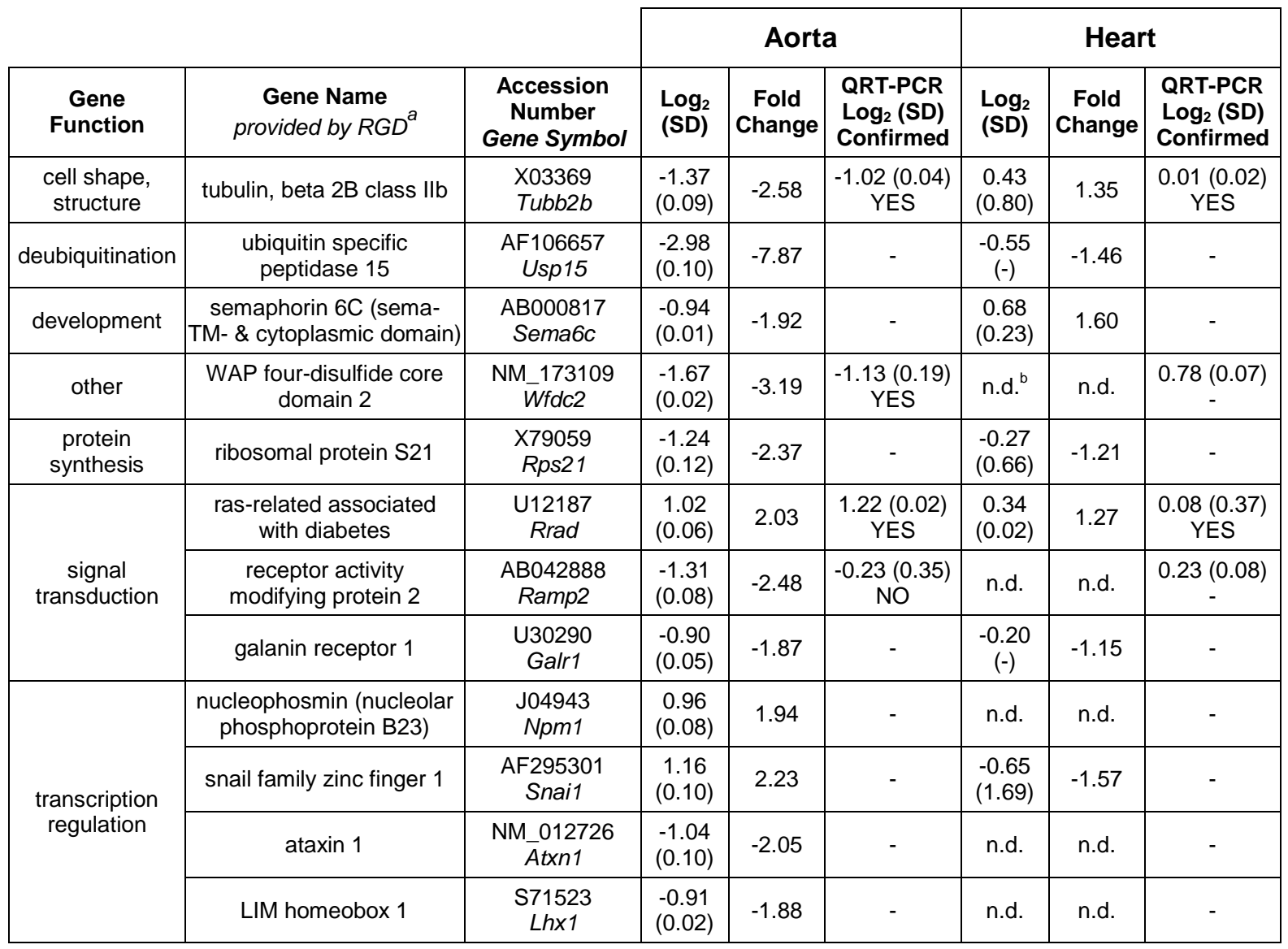

Values show gene expression in organs of nitrate-tolerant vs. non-tolerant rats. Log $_{2}$ ratio reaching at least \pm 0.90 and $p<0.05$ were considered as significant alterations. Altered expression of selected genes was confirmed by QRT-PCR.

${ }^{a} \mathrm{RGD}$ : rat genome database

${ }^{b}$ n.d.: not detectable 
Table 5. QRT-PCR results of selected genes of oxidative/nitrative/nitrosative stress in the heart and the aorta in response to chronic nitroglycerin pretreatment.

\begin{tabular}{|c|c|c|c|c|c|}
\hline \multirow[b]{2}{*}{ Gene Name (Symbol) } & \multirow[b]{2}{*}{$\begin{array}{l}\text { Accession } \\
\text { Number }\end{array}$} & \multicolumn{2}{|c|}{ Heart } & \multicolumn{2}{|c|}{ Aorta } \\
\hline & & $\log _{2}(\mathrm{SD})$ & $\begin{array}{l}\text { Fold } \\
\text { Change }\end{array}$ & $\log _{2}(S D)$ & $\begin{array}{l}\text { Fold } \\
\text { Change }\end{array}$ \\
\hline matrix metalloproteinase 2 (MMP2) & NM_031054 & $0.69(0.26)$ & 1.61 & $1.35(0.1)$ & 2.55 \\
\hline matrix metalloproteinase 9 (MMP9) & NM_031055 & $-0.08(0.21$ & -1.06 & $0.30(0.25)$ & 1.23 \\
\hline matrix metalloproteinase 13 (MMP13) & AY135636 & $-0.16(1.09)$ & -1.12 & $-0.81(0.87)$ & -1.75 \\
\hline NADPH oxidase 1 (NOX1) & NM_053683 & $0.44(0.23)$ & 1.36 & $0.25(0.45)$ & 1.19 \\
\hline NADPH oxidase 2 (CYBB) & AJ295950.1 & $0.50(0.61)$ & 1.41 & $0.14(0.3)$ & 1.10 \\
\hline NADPH oxidase 4 (NOX4) & NM_053524 & $1.09(0.03)$ & 2.13 & $1.36(0.13)$ & 2.57 \\
\hline nitric oxide synthase 1 (NOS1) & NM_052799 & $-0.18(0.2)$ & -1.13 & $-0.73(0.11)$ & -1.66 \\
\hline nitric oxide synthase 2 (NOS2) & NM_012611 & $1.42(0.21)$ & 2.68 & $1.10(0.07)$ & 2.14 \\
\hline nitric oxide synthase 3 (NOS3) & NM_021838 & $0.12(0.28)$ & 1.09 & $0.23(0.28)$ & 1.17 \\
\hline superoxide dismutase 1 (SOD1) & NM_017050 & $0.34(0.04)$ & 1.27 & $0.48(0.43)$ & 1.39 \\
\hline superoxide dismutase 2 (SOD2) & $X 56600$ & $-0.06(0.28)$ & 0.96 & $1.73(0.08)$ & 3.32 \\
\hline superoxide dismutase 3 (SOD3) & BC061861 & $0.48(0.11)$ & 1.39 & $1.15(0.18)$ & 2.22 \\
\hline tissue inhibitor of MMP1 (TIMP1) & NM_053819 & $-0.20(0.61)$ & -1.15 & $-1.31(0.12)$ & -2.48 \\
\hline tissue inhibitor of MMP2 (TIMP2) & NM_021989 & $-0.07(0.82)$ & -1.05 & $-0.04(0.47)$ & -1.03 \\
\hline tissue inhibitor of MMP4 (TIMP4) & NM_001109393 & $-1.40(0.37)$ & -2.64 & $-0.15(0.13)$ & -1.11 \\
\hline
\end{tabular}

Values show gene expression in organs of nitrate-tolerant vs. non-tolerant rats. $\log _{2}$ ratio at least \pm 0.90 and $p<0.05$ were considered as significant alterations (indicated with values in bold). 


\section{Supplementary Material 1.}

Supplementary Table 1. Primers used for verifying DNA microarray results with QRT-PCR.

\begin{tabular}{|c|c|c|c|}
\hline $\begin{array}{c}\text { Gene Name } \\
\text { provided by } R G D^{a}\end{array}$ & $\begin{array}{l}\text { Accession } \\
\text { Number }\end{array}$ & Forward primer & Reverse primer \\
\hline actin, beta & NM_031144 & GGAAATCGTGCGTGACATTAAA & TGCGGCAGTGGCCATC \\
\hline agrin & M64780 & TGGTTGTCCATGCTATTGACTTG & GCCAGGCAAAATAGAAGCAGAT \\
\hline CD59 molecule, complement regulatory protein & NM_012925 & CAGGCCCTAGCAGGCATTT & TCGACATCCAGGTGAAGCATAT \\
\hline complement component 4 binding protein, beta & NM_016995 & T GGAGCGCTTCCGTGACT & TGTCCCAACTCTCTGTGTTACTTGA \\
\hline fibroblast growth factor receptor 1 & D12498 & CGGAAGCAACGCTGTGAAT & TGGTAGATGGCAGCAATGGA \\
\hline HAUS augmin-like complex, subunit 1 & AF092207 & CCTGCAGTCTTCACCCGAAT & TGGTCAGATCCTTGCCCTTT \\
\hline hydroxysteroid 11 -beta dehydrogenase 2 & NM_017081 & GGAGAAGCGCAAGCAACTG & TGCTCAATGTAGTCTTCACCATAGG \\
\hline indian hedgehog protein & AF162914 & CCGCGCGGTGGATATC & CGCGCCAGTAGTCCGTACTT \\
\hline keratin 9 & NM_153476 & GCCTTCTGCTCAGCATCAAGA & GCCGCCTTCAAGGAGCTT \\
\hline leukemia inhibitor factor receptor alpha & D86345 & TCCTGGCGAAAGCTCTGAGA & TGATGGGTGGGCAGTAAGACA \\
\hline mast cell protease 1 & U67915 & TTTGCCAACTGCTCCTTGGT & CATGGCCAGAAGCACATCCT \\
\hline microtubule-associated protein 6 & NM_017204 & CCAAAGACACAGGTACGGATCTG & GCCCTTAGTTGGCTCAGGAA \\
\hline potassium voltage-gated channel, subfamily $\mathrm{H}$, member 2 & U75210 & CCTTTTGCAGACCACCCTTGT & GACACACGAGCCCCCATTAA \\
\hline potassium voltage-gated channel, subfamily $\mathrm{H}$, member 3 & NM_017108 & CAGCCGGGAAACCGACTA & AGTCGCACGGTTGGCATT \\
\hline ras-related associated with diabetes & U12187 & GCAGTACCGAGCCCTGACA & GCAGCCATCATGTTCTTGGA \\
\hline receptor activity modifying protein 2 & AB042888 & GATTCGCTCAGTTCTGGAGACA & GCGCCCCAGCAGCAT \\
\hline taste receptor, type 2, member 119 & AF227140 & AAACACAGACACACTGGACAAGCT & TCTGCAGCACCTGTTCAGACA \\
\hline thyroid stimulating hormone, beta & NM_013116 & GCTCATTCTGCTGCTGGTCAT & TCTTCAGTCTCCTTCAGCAGGAA \\
\hline tubulin, beta $2 \mathrm{~B}$ class IIb & X03369 & TGTCCTTTGCCCTGGTGAA & CTGGCCTAAGTGGACACATGAG \\
\hline vasoactive intestinal peptide receptor 1 & NM_012685 & CCTGACCATCAACACCACCAT & GGAAGAAACAGTTTGCCATTGATA \\
\hline WAP four-disulfide core domain 2 & NM_173109 & CGGCTGCGGCTCTGTCT & GCGGTCCTGGAGAGTTTTCC \\
\hline
\end{tabular}

${ }^{a} \mathrm{RGD}$ : rat genome database 
Supplementary Table 2. Primers used for QRT-PCR testing selected genes related to oxidative/nitrrative/nitrosative stress.

\begin{tabular}{|l|l|l|l|}
\hline \multicolumn{1}{|c|}{ Gene Name (Symbol) } & $\begin{array}{c}\text { Accession } \\
\text { Number }\end{array}$ & \multicolumn{1}{|c|}{ Forward primer } & \multicolumn{1}{c|}{ Reverse primer } \\
\hline beta-actin & NM_031144 & CCCGCGAGTACAACCTTCT & CGTCATCCATGGCGAACT \\
\hline matrix metalloproteinase 2 (MMP2) & NM_031054 & GCGCTTTTCTCGAATCCAT & GGGTATCCATCTCCATGCTC \\
\hline matrix metalloproteinase 9 (MMP9) & NM_031055 & CCTCTGCATGAAGACGACATAA & GGTCAGGTTAGAGCCACGA \\
\hline matrix metalloproteinase 13 (MMP13) & AY135636 & GATGTGTGGCACAGTGGTTT & GCCCAGGAGGCTTAGACTCA \\
\hline NADPH oxidase 1 (NOX1) & NM_053683 & GGCATCCCTTTACTCTGACCT & TGCTGCTCGAATATGAATGG \\
\hline NADPH oxidase 2 (CYBB) & AJ295950.1 & GCTGGGATTGGAGTCACG & CCTGCACAGCCAGTAGAAGTAG \\
\hline NADPH oxidase 4 (NOX4) & NM_053524 & CCCTGTGCTGGCCACTAA & TGGTGCCTCTCAGAGTCTACAAG \\
\hline nitric oxide synthase 1 (NOS1) & NM_052799 & GATGAGGCACCCCAACTCT & CCTTTACGGGGAAAGAAACG \\
\hline nitric oxide synthase 2 (NOS2) & NM_012611 & ACCATGGAGCATCCCAAGTA & CAGCGCATACCACTTCAGC \\
\hline nitric oxide synthase 3 (NOS3) & NM_021838 & TGACCCTCACCGATACAACA & CGGGTGTCTAGATCCATGC \\
\hline superoxide dismutase 1 (SOD1) & NM_017050 & CCAGCGGATGAAGAGAGG & GGACACATTGGCCACACC \\
\hline superoxide dismutase 2 (SOD2) & X56600 & TTCCTCTAATTGGGCTCAGG & AGCTCTGGGGAGACACGTA \\
\hline superoxide dismutase 3 (SOD3) & BC061861 & CTTGGGAGAGCTTGTCAGGT & CACCAGTAGCAGGTTGCAGA \\
\hline tissue inhibitor of metalloproteinase 1 (TIMP1) & NM_053819 & CAGCAAAAGGCCTTCGTAAA & TGGCTGAACAGGGAACACT \\
\hline tissue inhibitor of metalloproteinase 2 (TIMP2) & NM_021989 & CTGGACGTTGGAGGAAAGAA & ACAGAGGGTAATGTGCATCTTG \\
\hline tissue inhibitor of metalloproteinase 4 (TIMP4) & NM_001109393 & AGGGAGAGCCTGAATCATCA & GCACTGCATAGCAAGTGGTG \\
\hline
\end{tabular}




\section{Supplementary Material 2.}

\section{Methods}

In order to analyze the transcript levels of selected vascular signaling molecules by QRT-PCR separate experiments were performed. To induce vascular nitrate tolerance, male Wistar rats $(320-400 \mathrm{~g})$ were given nitroglycerin $(100 \mathrm{mg} / \mathrm{kg}$ subcutaneously) or its vehicle (lactose) 3 times a day for 3 days. The animals were used for tissue sampling on the fourth day, approximately $12 \mathrm{~h}$ after the last injection. Animals were anesthetized with $50 \mathrm{mg} / \mathrm{kg}$ sodium pentobarbital and given $500 \mathrm{U} / \mathrm{kg}$ heparin intravenously. Hearts from non-tolerant and nitrate-tolerant rats $(n=6$ in each groups) were then isolated and perfused in Langendorff mode with oxygenated, normothermic Krebs-Henseleit buffer for $5 \mathrm{~min}$, as described in earlier works. Following isolation of the heart, the entire thoracic and abdominal aorta was dissected, placed in ice cold saline and trimmed of excess connective tissue. Then the ventricles and aortas from both experimental groups were blotted, immediately frozen, and powdered with a pestle and mortar in liquid nitrogen for RNA preparation.

For QRT-PCR, $1 \mu \mathrm{g}$ samples of total RNA from individual samples were reverse transcribed using High Capacity Archive Kit (ABI, Foster City, California, USA). The reactions were carried out in final volume of $30 \mu \mathrm{l}$. The RT reaction mixture was next diluted 2 times with sterile water. $1 \mu \mathrm{l}$ of the diluted reaction mix was used for QRT-PCR using SybrGreen dye. SybrGreen protocol were carried out with FastStart SYBR Green Master (Roche) in a RotorGene real-time QPCR machine (Corbett Research, Mortlake, Australia) according to manufacturer's instructions at a final primer concentration of 250 nM under the following conditions; 10 min at $95^{\circ} \mathrm{C}, 45$ cycles of $95^{\circ} \mathrm{C}$ for $15 \mathrm{sec}, 60^{\circ} \mathrm{C}$ 
for $25 \mathrm{sec}$ and $72{ }^{\circ} \mathrm{C}$ for $25 \mathrm{sec}$. The fluorescence intensity of SybrGreen dye was detected after each amplification step. Melting temperature analysis was done after each reaction to check the quality of the reaction. PCR primers were designed using the Universal Probe Library / Assay Design Center of Roche (http://lifescience.roche.com/ assay design center). A non-template control was used for each primer to check the primer dimer formation. All the Ct values were normalized to rat CyclophyllinA gene.

Primers used for QRT-PCR testing selected genes of vascular signaling molecules.

\begin{tabular}{|l|l|l|l|}
\hline \multicolumn{1}{|c|}{ Gene Name (Symbol) } & $\begin{array}{c}\text { Accession } \\
\text { Number }\end{array}$ & \multicolumn{1}{|c|}{ Forward primer } & \multicolumn{1}{c|}{ Reverse primer } \\
\hline phosphodiesterase 1A (PDE1A) & NM_030871.1 & $\begin{array}{l}\text { GCAACGCCTGAAAGGAA } \\
\text { TAC }\end{array}$ & $\begin{array}{l}\text { CGACAACGTTGACATC } \\
\text { ACCT }\end{array}$ \\
\hline phosphodiesterase 2A2 (PDE2A2) & U21101 & $\begin{array}{l}\text { CAACAAGCTTGGAGGAG } \\
\text { ACTTC }\end{array}$ & $\begin{array}{l}\text { GAGCACCGTGCCTGT } \\
\text { GTA }\end{array}$ \\
\hline $\begin{array}{l}\text { angiotensin II receptor, type 1a } \\
\text { (AGTR1a) }\end{array}$ & NM_030985.4 & $\begin{array}{l}\text { CACCCGATCACCGATCA } \\
\text { C }\end{array}$ & $\begin{array}{l}\text { CAGCCATTTTATACCA } \\
\text { ATCTCTCA }\end{array}$ \\
\hline $\begin{array}{l}\text { angiotensin II receptor, type 1b } \\
\text { (AGTR1b) }\end{array}$ & NM_031009.2 & $\begin{array}{l}\text { GACACACACAGCCTTTC } \\
\text { CAG }\end{array}$ & $\begin{array}{l}\text { GCTCTCTGACACTATT } \\
\text { TAAAATGCAC }\end{array}$ \\
\hline $\begin{array}{l}\text { guanylate cyclase 1, soluble, beta 2 } \\
\text { (GUCY1B2) }\end{array}$ & NM_012770.1 & $\begin{array}{l}\text { GGAACACAGACCATCAG } \\
\text { CAA }\end{array}$ & $\begin{array}{l}\text { CCCAGCAAGTGTGACT } \\
\text { TCATT }\end{array}$ \\
\hline $\begin{array}{l}\text { guanylate cyclase 1, soluble, beta 3 } \\
\text { (GUCY1B3) }\end{array}$ & NM_012769.2 & $\begin{array}{l}\text { GCCAATGCAAGTCTGGT } \\
\text { TTC }\end{array}$ & $\begin{array}{l}\text { CCATTCAGTTTTCATCC } \\
\text { TGGTT }\end{array}$ \\
\hline $\begin{array}{l}\text { guanylate cyclase 1, soluble, alpha } \\
\text { 2 (GUCY1A2) }\end{array}$ & NM_023956.1 & $\begin{array}{l}\text { GCTGCAGTAGTGTCTCC } \\
\text { AAGC }\end{array}$ & $\begin{array}{l}\text { AGCTGAAGGACTCGGA } \\
\text { TGAA }\end{array}$ \\
\hline $\begin{array}{l}\text { guanylate cyclase 1, soluble, alpha } \\
\text { 3 (GUCY1A3) }\end{array}$ & NM_017090.2 & $\begin{array}{l}\text { GCTTTGACCAACAGTGT } \\
\text { GGA }\end{array}$ & $\begin{array}{l}\text { AATATGCATCTCCGAT } \\
\text { GGTCTC }\end{array}$ \\
\hline
\end{tabular}




\section{Results}

QRT-PCR results of selected genes of vascular signaling molecules in the heart and the aorta in response to chronic nitroglycerin pretreatment.

\begin{tabular}{|c|c|c|c|c|c|}
\hline \multirow[b]{2}{*}{ Gene Name (Symbol) } & \multirow[b]{2}{*}{$\begin{array}{l}\text { Accession } \\
\text { Number }\end{array}$} & \multicolumn{2}{|c|}{ Heart } & \multicolumn{2}{|c|}{ Aorta } \\
\hline & & $\log _{2}(\mathrm{SD})$ & $\begin{array}{c}\text { Fold } \\
\text { Change }\end{array}$ & $\log _{2}(\mathrm{SD})$ & $\begin{array}{c}\text { Fold } \\
\text { Change }\end{array}$ \\
\hline phosphodiesterase 1A (PDE1A) & NM_030871.1 & n.d. ${ }^{b}$ & n.d. & n.d. & n.d. \\
\hline phosphodiesterase 2A2 (PDE2A2) & U21101 & $0.20(0.55)$ & 1.15 & $-0.28(0.55)$ & -1.22 \\
\hline angiotensin II receptor, type 1a (AGTR1a) & NM_030985.4 & $0.06(0.37)$ & 1.04 & $-1.02^{\mathrm{a}}(1.64)$ & -2.03 \\
\hline angiotensin II receptor, type $1 \mathrm{~b}$ (AGTR1b) & NM_031009.2 & $0.19(0.57)$ & 1.14 & $-0.24(1.09)$ & -1.18 \\
\hline guanylate cyclase 1 , soluble, beta 2 (GUCY1B2) & NM_012770.1 & n.d. & n.d. & n.d. & n.d. \\
\hline guanylate cyclase 1 , soluble, beta 3 (GUCY1B3) & NM_012769.2 & $0.44(0.36)$ & 1.36 & $-0.17(0.73)$ & -1.12 \\
\hline guanylate cyclase 1 , soluble, alpha 2 (GUCY1A2) & NM_023956.1 & $-0.03(0.79)$ & -1.02 & $0.06(0.80)$ & 1.04 \\
\hline guanylate cyclase 1 , soluble, alpha 3 (GUCY1A3) & NM_017090.2 & n.d. & n.d. & n.d. & n.d. \\
\hline
\end{tabular}

Values show gene expression in organs of nitrate-tolerant vs. non-tolerant rats. $\log _{2}$ ratio at least \pm 0.90 and $p<0.05$ were considered as significant alterations.

${ }^{a}$ not significant change $(p>0.05)$

${ }^{b}$ n.d.: not detectable 